\title{
NORMATIVE DIMENSIONS OF MARITAL AND FAMILY INTIMACY IN THE POLISH STUDENTS' EVALUATION
}

\section{Sroczyńska}

\author{
Cardinal Stefan Wyszyński University in Warsaw, Institute of Sociology, \\ Wóycickiego St. 1/3, building 23, 01-938 Warsaw, \\ mariasroczynska@wp.pl
}

\begin{abstract}
The article discusses the attitude of Polish students to the normative dimension of marital and family intimacy. The evaluation covers fi ve issues: premarital sexual intercourse, the use of contraceptives, marital infi delity, divorce and termination of pregnancy. The results of the survey research performed in 2017 on Polish students were compared with the outcome of the dynamic research conducted on the academic youth since the late 1980s. Marital and family morality based on values and principles referring to the authority of Roman Catholicism is undergoing signifi cant changes. On the one hand the individualization and subjectivization of the content related to intimate life and on the other hand the revitalization of moral categories perceived primarily as individual responsibility and less frequently as a part of a religious system are observed. Therefore, it would be worthwhile to compare the results of the conducted research with the students' moral evaluations formulated against the background of other societies and the religious cultures prevalent in them, including the Orthodox Church.

Keywords: marital and family intimacy, Polish students, moral evaluation, religious norms.
\end{abstract}

Introduction - religion and morals in the post-modern world. Scholars studying social life, especially its axionormative sphere, agree that social control systems such as religion, morality, law, customs and fashion are partially autonomous and partially interdependent, [cf. 1;2].Although it is possible to imagine a society abandoning strictly religious $^{1}$ symbols and meanings, a social life devoid of references to moral categories good and evil - is a utopia. The concept of intimacy, related to the most inner, personal and private sphere and intended for the closest persons, is connected with the axionormative dimension regulating the realm of eroticism, sexuality, love, and hence also the marital and family life. According to Anthony Giddens, the socio-cultural processes related to postmodernism have resulted in a far-reaching emancipation in this area, both in the context of absolute meanings with a religious background and social conformities internalized by individuals. In consequence a growing interest in the concurrent love model and the so-called pure relations can be observed

1 The researcher Mircea Eliade believes that this is not entirely possible due to the preservation of the so-called residual sacrum [3].

(C) Sroczyńska M., 2017 
[4]. Nowadays, there is an increasing, even though not fully realized, heterodoxy (understood as views and activities different from the doctrine of faith propagated by a given religious institution) and growing relativistic tendencies. Religion and morals are increasingly forming separate systems for regulating human behavior. On the other hand, although to a lesser extent, there is a visible shift towards rudimentary content (often rooted in the substantial sacrum), perceived as objective determinants of a valuable individual life and social order. As is rightly claimed by Zygmunt Bauman «...human reality is unordered and ambiguous, and also moral decisions, unlike abstract ethical principles, are ambivalent» [5, p. 45]. These problems, coexisting with the sociological narration, are defi ned on the one hand - through the prism of institutionalization and privatization of religion and morality, and on the other by processes of secularization, desecularization and marketization [6]. In the Polish society they used to be connected with the systemic transformation and are presently associated with the dynamics of refl exive modernization [7].

The morals and customs of Polish society are characterized by a specifi c strategy of adaptation to diverse systemic conditions. It is connected with such features as: a stability of orientation on the social capital based on the family and local environment, the defi cit of public morality and the identifi cation at the level of primary structures (nation and Church of representation) [cf. 8]. Only a decade ago, the most probable scenario was that of a relative stabilization of references between the religious and moral spheres $[9 ; 10 ; 11$, p. 81-91]. Today one can observe tendencies separating those systems, which results in an increasing importance of decisions based on the autonomous conscience criteria. The individualization trend largely reduces the differences between men and women (especially in younger age categories), and promotes «situational tinkering» in the area of religious and moral meanings (e.g. in the sphere of intimacy) $[12 ; 13 ; 14]$.

The tendencies to absolutize the moral content are far less common, which implies their relation with religious values. The globalization and modernization produce a landscape of contradictions - on the one hand the sacrum is dispersed and on the other it emerges in non-religious areas, whereas the strong emphasis on an individual's self-fulfi llment is accompanied by the need for bonds and shared emotions. It provokes the formation of new forms of responsibility that in the intimate sphere oscillate around the negotiation model.

Characteristics of research. The research proper was conducted at the Department of Sociology of Religion at the Institute of Sociology, in cooperation with the Institute of the Catholic Church Statistics of the SAC, at the turn of April and May 2017. It covered only full-time studies in state universities. This decision was made to preserve the characteristics of the samples in comparative diachronic studies. In all the surveys in 1988, 1998, 2005 and 2017, the research type $\mathrm{f} 2 \mathrm{f}$ of the auditory type PAPI was applied. Based on the nationwide structure of academic youth it was established that 1067 students would be examined. The effective sample was $\mathrm{n}=794$ ( $\mathrm{yy}=0.74$ ) students. The basic reason for the unit non-response was the refusal to participate in the survey. In order to match the sample structure to the population sample the rim weighting of the RAKE type was used. Respondents' statements were anonymous in order to comply with the standards of ESOMAR and PKJPA [15].

The students of the following fi elds of studies: Sociology, Economics and Man in Cyberspace at the Cardinal Stefan Wyszyński University in Warsaw provided the network of survey interviewers. 
In the literature on the subject students are defi ned as a social group identifi ed by specifi c activities (academic studies), patterns of behaviour and leisure, sharing a social space and being embedded in peer groups. The period of studies provides time for development and selfimprovement, hence the students are considered a socially privileged group [16, pp. 33-34].

The analyzed sample of 2017 is dominated by women (59.2\%) with $40.8 \%$ of men, students of mathematical and natural sciences (including medicine) account for $65.7 \%$ of the respondents and students of humanities and socio-economic sciences represent $34.3 \%$ of the group. Almost half of the respondents come from the rural environment and from small towns with up to 50,000 inhabitants, nearly every seventh student represents a metropolitan agglomeration, and every eighth one - a city with 100,000 to 250,000 inhabitants. The number of residents of large cities (up to 500,000) and small cities $(50-100,000)$ is slightly smaller, they are represented by every fi fth respondent.

Although the parents' education structure still shows higher fi gures for mothers, the declarations of the respondents representing the generation of children born at the beginning of the transformation show that these differences have fl attened. The results of comparative research reveal increasingly better education of subsequent generational cohorts of Poles [cf. 17]. These issues correspond with the evaluation of the family's fi nancial situation - almost $70 \%$ of respondents defi ne it as very good or good and every fourth person declares that their living standard is average, whereas negative responses appear only sporadically.

The vast majority of the youth belong to Roman Catholic Church (84.5\%), and every tenth person does not identify themselves with any denomination. Only few respondents declare their relationship with Orthodoxy, Protestantism, Judaism, Islam ( $2.1 \%$ in total), as well as with other minority groups. Nearly $60 \%$ of respondents regard themselves as believers (including $11.7 \%$ of deep believers), $17 \%$ are undecided but attached to a religious tradition whereas $12 \%$ are indifferent. One in ten students admits to be a non-believer. Most of the respondents participate in a religious worship either systematically (every third respondent) or non-systematically (every fourth respondent). Nearly $20 \%$ of the academic youth participate in religious practices rarely and slightly over $13 \%$ do not do it at all. Thus, slightly over one third of students have signifi cantly weakened or broken off the ritual bond with the religious community.

Normative dimension of marital and family intimacy in the evaluation of students. One of the issues dealt with in the research «Youth and Values 2017» was an attempt to operationalize moral evaluations in the context of behaviours violating the normative order of the intimate sphere, identifi ed with the model of Roman Catholic religion [Figure 1]. The opinions concerned fi ve issues: sexual intercourse before marriage, the use of contraceptives, marital infi delity, divorce and termination of pregnancy.

Source: Author's calculations based on the «Youth and Value 2017» study. The highest rates of moral liberalism concern the use of contraceptives and sexual intercourse before marriage. In each case approx. two thirds of students fi nd these activities acceptable. It highlights clearly the transformations that the contemporary form of intimacy has undergone, manifested as a detachment of sexuality from marriage, procreation and the traditional family. Out of the surveyed issues being in contradiction to the teaching of the Catholic Church it is the use of contraceptives and the pre-marital sex that received the highest acceptance of 
students. The Catholic Church treats the sacramental marriage as a communion of persons open to both the bond-forming and the procreating dimensions [18, p. 532-533].

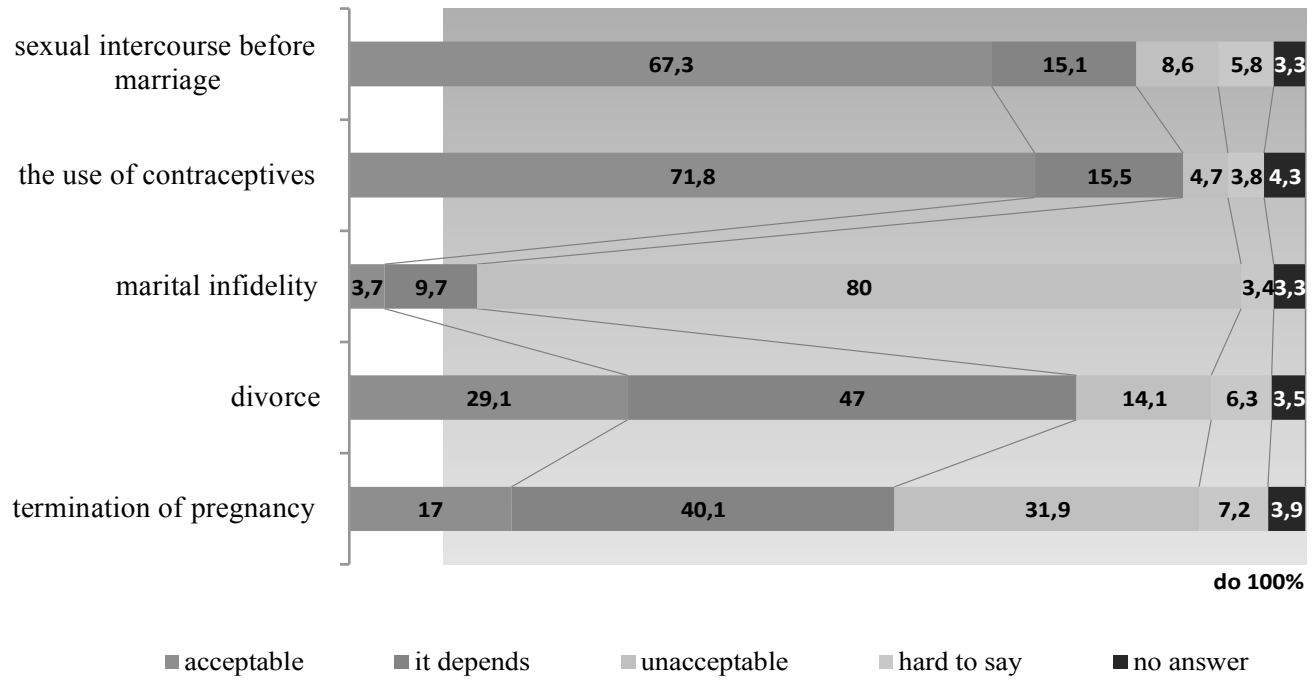

Chart 1. Moral assessment of violating the normative dimension of marital-family intimacy (in per cent )

Divorce is accepted by every third respondent, the majority of students connect the breakdown a of marriage with the relativization of moral evaluation (almost half of the indications). On the other hand, within the «cultural obviousness» is a negative evaluation of marital infi delity (declared by $80 \%$ of respondents), perceived as an act that undermines the essence of sexual, emotional and psychological bond between partners. Thus, students, in the vast majority do not approve of actions violating both religious and secular criteria of goodness in interpersonal relations. Termination of pregnancy, on the other hand, does not evoke such unambiguous reactions, it is unacceptable for every third respondent whereas almost half of the surveyed students believe the evaluation of abortion depends on special circumstances (as can be presumed - allowed by the law in force in Poland) ${ }^{1}$. Only every sixth respondent supports the pro-choice attitude as far as the possibility of terminating pregnancy is concerned. Whether the conception of human life is attributed to the sphere of the sacrum or to secular values has a signifi cant impact on the way in which members of a given society evaluate abortion.

The interpretation of the system of research variables provides a context for the emer-

1 Since 1993, abortion has been legally permitted in special circumstances specifi cally stipulated by the law. These include: threat to the health or life of the mother, irreversible impairment of the fetus or the occurrence of a prohibited act (rape, iniquitous act) - Act on family planning, protection of the human fetus and the conditions for the legally permissible termination of pregnancy, dated 7 January 1993 [cf.19, access: 19/12/2016]. 
gence of interesting relations Women slightly less commonly than men approve of pre-marital sex (difference of 4 percentage points), at the same time more often indicating the category «it depends». In the case of divorce female students indicate the option «it depends» more often than male students, with the difference of 10 percentage points, at the same time being less strict in their evaluations (difference of 5 percentage points). As far as the place of permanent residence is concerned, the number of opinions that accept premarital sex (contradictory to the teaching of the Church) increases together with the transition from small (60\% indications in rural communities) to larger communities, remaining a «cultural obviousness» in metropolitan agglomerations (almost $82 \%$ ). The use of contraception is evaluated in a similar way, whereas the lowest rate of non-acceptance of pre-marital sex occurs in medium-sized cities with 100,000 to 250,000 inhabitants $(4.0 \%)$. The orthodoxy of religiously motivated views related to the acceptability of divorce is particularly evident in the case of people from smaller local communities. Then, students assessing the fi nancial status of their families as very good are also those who indicate the unacceptability of premarital sex (approx. only $12 \%$ of acceptance), whereas those with poor fi nancial situation are the least strict $(85 \%$ of acceptance). With regards to contraceptives one can observe the fear of an unwanted pregnancy complicating the diffi cult life situation of young people, anticipated by some respondents. On the other hand, a better assessment of the fi nancial condition of one's own family favours a more positive attitude towards divorce, but in this case, the opinions are divided (people assessing this condition as very good most strongly accept the indissolubility of marriage). Marital infi delity is regarded as unacceptable by women more often than by men ( $85 \%$ and $75 \%$, respectively), by respondents studying mathematical and natural sciences more often than by those studying humanities and social-economic sciences (the difference of seven percentage points), by people with the permanent place of residence in smaller local communities - in villages and cities with up to 100,000 inhabitants, and by those whose families have a good fi nancial situation. In a rural environment only $10 \%$ of students recognize the possibility of a pregnancy termination (and $40 \%$ of respondents oppose it), while in the largest cities (over 500,000 inhabitants) the attitudes are to the largest extent antagonized permissivism or moral rigorism are manifested by every fourth respondent. Attitudes that accept the possibility of abortion in special circumstances are most commonly manifested by people from small and medium-sized cities, ranging from 50,000 to 250,000 of residents.

An important role in assessing sexual relation before the church wedding, the use of contraceptives or divorce is played by two basic aspects of institutionally oriented religiosity the attitude to faith and religious practices [cf. 20, pp.286-295], which is also confi rmed by the study of 2017. However, even strong identifi cation with religious faith does not guarantee full acceptance of the moral code related to it. The growing distance to the faith is accompanied by the acceptance of premarital sex, but a clear qualitative «leap» can be observed between those declaring themselves as believers and the other categories of respondents. The contradictory positions in the assessment of marital infi delity is especially evident between

They are the result of the data analysis included in the cross tables.

2 Students coming from small towns, up to 50,000 inhabitants are an exception here, which can be associated with the mechanism of relative privilege. Rural environment is considered by them too conservative in the sphere of customs. 
respondents who are deep believers, believers and undecided (over 4/5 of respondents in each category), and people who are religiously indifferent and non-believers, whose strict indications are lower by approx. 20 percentage points on average. The evaluation of abortion reveals a downward trend with regard to connecting religious faith with moral rigorism - the deep believers outnumber non-believers nearly ten times (59\% and $6 \%$ respectively). The degree of liberalism with regard to abortion increases when respondents are less involved religiously (however, the persons indifferent in matters of faith express less acceptance of pregnancy termination than the undecided ones).

There is a similar tendency in the case of those involved in religious practices, although dedication in this area is not as much correlated with the acceptance of the sixth commandment as the religious faith. Among those regularly participating in Sunday mass and religious holidays there is a signifi cant difference of views, nearly two fi fths accept departure from the religious norm, almost every fourth is against such a departure, and almost every third person makes the opinion dependent on the wider context. Non-practicioners do not manifest rigorous attitudes, and only every eleventh respondent participating in worship has rare moments of doubt in this matter, e.g. in relation to important religious holidays or rites of passage (weddings, funerals). Thus, religious identifi cation on the level of faith appears to be a more important correlate of morality and customs than the fact of ritual involvement, which is also refl ected in the evaluation of the use of contraceptives and of divorce. In the group of deep believers, only every third person allows the use of contraceptives, while among non-believers this applies to over $90 \%$ of respondents; in the opposing categories: «systematic participation in religious practice» and «no participation in religious practice» the differences are smaller and concern 40 percentage points. In the case of the divorce evaluation faith and religious practices correspond with each other having similar values; therefore, the smaller the ritual activity of the examined youth, the more common the liberal attitude to divorce (it refers to nearly two fi fths in the group of regular practitioners and to over $90 \%$ of non-practitioners). There is also a visible linear decrease in moral rigorism in the context of marital infi delity the differences between regular practitioners and non-practitioners amount to over 20 percentage points $(91.3 \%$ and $69.8 \%$ respectively). The decline in the level of participation in religious worship favours an almost fi vefold decrease in orthodoxy in the evaluation of abortion (while 58\% systematic practicioners evaluate it in accordance with the Church teaching, the number of non-practicioners amounts to merely $12 \%$ ). The acceptability of pregnancy termination increases with young people drifting apart from religious practices ${ }^{1}$.

The attitudes of students to selected norms of marital and family morals in the context of dynamic research. An interesting aspect of the discussed subject matter is connected with the possibility of studying both the continuity and the change in students' opinions in 1988, 1999, 2005 and 2017, seen from the perspective of dynamic research ${ }^{2}$.

1 Non-practitioners express such opinions seven times more often than those regularly participating in the Holy Mass on Sundays and religious holidays, and non-religious people present such views nine times more often.

2 The fi rst survey was conducted at the end of the 1980s, the «eve of « the systemic transformation in Poland, the second 11 years later (on the threshold of the second millennium), the third after six years - in the context of important social events (death of Pope John Paul II and a year earlier - Poland's 
Evaluation of sexual relation before the church wedding in the years

1988, 1999, 2005 and 2017 (in per cent)

\begin{tabular}{|c|c|c|c|c|c|c|}
\hline \multirow{2}{*}{ Year of research } & \multicolumn{7}{|c|}{ Categories } \\
\cline { 2 - 7 } & Total & acceptable & it depends & unacceptable & hard to say & no answer \\
\hline $\mathbf{1 9 8 8}(\mathrm{N}=350)$ & 100.0 & 41,7 & 22,0 & 22.3 & 10,6 & 3,4 \\
\hline $\mathbf{1 9 9 9}(\mathrm{N}=523)$ & 100.0 & 64,2 & 13,4 & 13.0 & 6,7 & 2,7 \\
\hline $\mathbf{2 0 0 5}(\mathrm{N}=1086)$ & 100.0 & 63,9 & 16,8 & 8.1 & 5,2 & 6,1 \\
\hline $\mathbf{2 0 1 7}(\mathrm{N}=794)$ & 100.0 & 67,3 & 15,1 & 8.6 & 5,8 & 3,3 \\
\hline
\end{tabular}

\section{Source: Department of Sociology of Religion, UKSW and Institute of Statistics of} the Catholic Church SAC. The data analysis reveals the progressivity of students' moral liberalism visible in the evaluation of pre-marital life [Table 1], the largest qualitative leap, however, (more than 20 percentage points) accompanied the entry of Polish society into the political and economic transformation. It had signifi cant consequences in all spheres of public and private life of Poles, especially in the area of religious, moral and customs-related orientations of young people, who were more willing to adopt the ideology of consumerism than other social groups. At the end of 1980s evaluating the premarital sex against a broader background or the recognition of its unacceptability were most common, and the subsequent weakening of rigorism (especially over the last 12 years) occurred at a slower pace, taking a more stable form. Currently, two thirds of students accept disobeying religious norms regarding sexuality, but the percentage of respondents who relate such an attitude to an emotional bond between partners or its absence remains relatively high [cf. 21]. The number of people (every eleventh respondent) opposed to liberal tendencies has also remained the same, which may mean that the secularization trend has stopped.

Table 2

Evaluation of the use of contraceptives in 1988, 1999, 2005 and 2017 (in per cent)

\begin{tabular}{|c|c|c|c|c|c|c|}
\hline \multirow{2}{*}{ Rok badań } & \multicolumn{7}{|c|}{ Kategorie } \\
\cline { 2 - 7 } & ogółem & $\begin{array}{c}\text { dopuszcza- } \\
\text { lne }\end{array}$ & to zależy & $\begin{array}{c}\text { niedopusz- } \\
\text { czalne }\end{array}$ & $\begin{array}{c}\text { trudno } \\
\text { powie-dzieć }\end{array}$ & $\begin{array}{c}\text { brak } \\
\text { odpowie-dzi }\end{array}$ \\
\hline $\mathbf{1 9 8 8}(\mathrm{N}=350)$ & 100,0 & 46,0 & 26,6 & 16,6 & 6,9 & 4,0 \\
\hline $\mathbf{1 9 9 9}(\mathrm{N}=523)$ & 100,0 & 74,0 & 11,3 & 7,1 & 5,5 & 2,1 \\
\hline $\mathbf{2 0 0 5}(\mathrm{N}=1086)$ & 100,0 & 65,3 & 13,2 & 5,9 & 5,1 & 10,6 \\
\hline $\mathbf{2 0 1 7}(\mathrm{N}=794)$ & 100,0 & 71,8 & 15,5 & 4,7 & 3,8 & 4,3 \\
\hline
\end{tabular}

\section{Source: Department of Sociology of Religion, UKSW and Institute of Statistics of} the Catholic Church SAC. Looking at the fi gures expressing the evaluation of the use of contraceptives in the context of dynamic studies one can observe the increase in the percentage of academic youth expressing their approval [Table 2]. The dynamics of this phenomenon, although more pronounced than in the evaluation of pre-marital sex, took the form of a

entry into the EU), and fi nally the last - after 12 years (in the conditions of political conservatism, economic strengthening of Poland and the revival of the national type of citizenship). 
quantum-leap increase during the fi rst decade of the transformation period. While at the end of the 1980s almost every second student accepted the use of contraceptives, a decade later the approval was expressed by as many as near three quarters of the respondents. Although in the year of Pope John Paul II's death the number of such declarations decreased, the percentage of adolescents evading the answer surprisingly increased (to $10 \%$ ), which may be related to the effect of cultural inadequacy (of a normative nature). Currently, two-thirds of students are in favour of moral liberalism as far as the broadly understood contraception is concerned. Over the period of nearly 30 years the percentage of orthodox indications decreased almost four times, which can be related to a stronger secularization trend in this area, the individualization of young people's reaction to the growing choice of birth control measures and the extended period preceding the independent marital and family life.

Divorce evaluation in 1988, 1999, 2005 and 2017 (in per cent)

Table 3

\begin{tabular}{|c|c|c|c|c|c|c|}
\hline \multirow{2}{*}{ Year } & \multicolumn{6}{|c|}{ Categories } \\
\cline { 2 - 7 } & Total & acceptable & it depends & unacceptable & hard to say & no answer \\
\hline $1988(\mathrm{~N}=350)$ & 100,0 & 22,6 & 50,0 & 19,4 & 3,4 & 4,6 \\
\hline $1999(\mathrm{~N}=523)$ & 100,0 & 36,5 & 39,0 & 16,8 & 5,4 & 2,3 \\
\hline $2005(\mathrm{~N}=1086)$ & 100,0 & 25,0 & 43,0 & 14,6 & 7,4 & 9,9 \\
\hline $2017(\mathrm{~N}=794)$ & 100,0 & 29,1 & 47,0 & 14,1 & 6,3 & 3,5 \\
\hline
\end{tabular}

Source: Department of Sociology of Religion, UKSW and Institute of Statistics of the Catholic Church SAC. As in the case of other forms of intimacy, the attitude of students to the dissolubility of marriage - from the late $1980 \mathrm{~s}$ - was also subject to certain changes (Table 3). The 1980s saw the lowest number of respondents in favour of divorce (over one fi fth), the highest number of people (almost 20\%) considered this phenomenon unacceptable, but at the same time half of the students approved of the situational morality. A signifi cant increase in the responses expressing the acceptability of divorce was observed at the end of the 1990s, which can be related to the expansive phase of Polish transformation, inspired by and also «copying» consumer and individualistic patterns of lifestyle in Western societies. Six years later, however, only every fourth respondent accepted the dissolubility of marriage, the indicator of moral rigorism (shared by every seventh respondent) ${ }^{1}$ leveled off for the next decade. The recent studies have shown a slight increase - up to nearly $30 \%$ - of divorce supporters (by four percentage points compared to 2005), as in the case of opinions that relate this to life situations (up to $47 \%$ ).

1 In 2005 (the last of John Paul II's pontifi cate) the percentage of no reply responses was the highest in the fourth surveys (every tenth respondent gave no answer), which can be referred to the socalled interviewer effect. 
Evaluation of marital infi delity in 1988, 1999, 2005 and 2017 (in per cent)

\begin{tabular}{|c|c|c|c|c|c|c|}
\hline \multirow{2}{*}{ Year } & \multicolumn{7}{|c|}{ Categories } \\
\cline { 2 - 7 } & Total & acceptable & $\begin{array}{c}\text { it } \\
\text { depends }\end{array}$ & unacceptable & hard to say & no answer \\
\hline $1988(\mathrm{~N}=350)$ & 100,0 & 1,7 & 23,1 & 62,9 & 8,3 & 4,0 \\
\hline $1999(\mathrm{~N}=523)$ & 100,0 & 7,6 & 24,3 & 60,0 & 5,2 & 2,9 \\
\hline $2005(\mathrm{~N}=1086)$ & 100,0 & 2,7 & 13,9 & 71,4 & 2,9 & 9,1 \\
\hline $2017(\mathrm{~N}=794)$ & 100,0 & 3,7 & 9,7 & 80,0 & 3,4 & 3,3 \\
\hline
\end{tabular}

Source: Department of Sociology of Religion, UKSW and Institute of Statistics of the Catholic Church SAC. It is also worth taking a look at the results of research on marital infi delity carried out at various times starting from the late 1980s. The most characteristic feature is the increase in moral rigorism from the beginning of the 21 st century - in 1988 and 1999 these indicators were similar and oscillated around $60 \%$ of responses, in 2005 a critical attitude to marital infi delity was expressed by two thirds of the respondents, and in 2017 it reached the sociological threshold of behaviour, defi ned as «cultural obviousness» (Table 4). It can therefore be assumed that the orientations of a vast majority of students, regardless of the adopted ideology - religious or secular - have shifted towards conservative, though presentistically understood, values of a personal and communal character. They are treated as the basis for a permanent relationship (primarily marital), an important determinant of the meaning of life and (in a broader context) of social order [cf. 22, pp. 112-128]. Despite the clash of various competitive axiological options, a permissive point of view based on egoistic self-realization, such as «together, apart», fi nds few supporters [23, pp. 15-32]. This does not mean, however, that in the community of students there is a consensus of views on intimate norms or that the most profound content of the teaching of religious institution is properly interpreted.

Evaluation of termination of pregnancy in 1988, 1999, 2005 and 2017 (in per cent)

\begin{tabular}{|c|c|c|c|c|c|c|}
\hline \multirow{2}{*}{ Year } & \multicolumn{7}{|c|}{ Kategorie } \\
\cline { 2 - 7 } & Total & acceptable & it depends & unacceptable & $\begin{array}{c}\text { hard to } \\
\text { say }\end{array}$ & no answer \\
\hline $1988(\mathrm{~N}=350)$ & 100,0 & 6,0 & 29,7 & 59,1 & 1,7 & 3,4 \\
\hline $1999(\mathrm{~N}=523)$ & 100,0 & 15,1 & 33,1 & 40,7 & 8,8 & 2,3 \\
\hline $2005(\mathrm{~N}=1086)$ & 100,0 & 11,2 & 33,0 & 42,2 & 4,3 & 9,3 \\
\hline $2017(\mathrm{~N}=794)$ & 100,0 & 17,0 & 40,1 & 31,9 & 7,2 & 3,9 \\
\hline
\end{tabular}


Source: Department of Sociology of Religion, UKSW and Institute of Statistics of the Catholic Church SAC. A comparison of the dynamic research results of the pregnancy termination evaluation broadens sociological knowledge with respect to the possible application of the secularization paradigm, which is particularly evident in the border dates of 1988 and 2017. During this period there was almost threefold increase in the indications regarding the acceptability of pregnancy termination, and the conditional declarations increased by 10 percentage points [Table 5]. At the same time, the percentage of respondents who considered abortion as an unacceptable act putting into question the dignity of human life decreased twice. In the years 1999-2005 there was a slight regress in the area of moral liberalism, which can be attributed to the last period of John Paul II's pontifi cate and attempts to shape the JP2 generation, focussed on the papal teaching, including the theology of the body [24].

Final comments. What direction does contemporary youth head? Is it towards individualized and unstable adaptation to the conditions determined by the transmissional cofi gurativeness of the generation of parents described by Margaret Mead [25], or rather towards the confl ict of generations? «Is it towards the increased arrogance of the extremists surrounding the increasingly distressed and sloppy center? Or maybe towards the supragenerational agreement that our world, known for double-dealing as a basic tool of survival and buying hope cannot be maintained any longer and or maybe towards an agreement (postponed for so long that it seems outrageous) about the need for renewal?» [26]. Citizens deprived of their share in the community are transforming themselves into consumers who treat the world as a «pasture and playground», focused on seeking their own well-being, and thus adopting a different hierarchy of values with regard to matters that human life is composed of [27;28;29]. Does this concern the moral sphere, including the relation to human life, those areas of intimacy that include sexuality and procreation? According to Wojciech Burszta, we live in interregnum times, and traditional patterns of social life give way to alternative ideas how to organize a collective existence in a manner regulated by standards, but not limiting the autonomy of individuals. This provides background for disputes called «culture wars», whose range and impact are not always realized [30].

Research conducted in the student environment confi rms the thesis that morals based on absolute values and unquestionable principles referring to the authority of religion are subject to signifi cant changes [cf.31]. On the one hand, we deal with the individualization and subjectivization of moral content in the convention «together, apart» [32], and on the other - with the revitalization of «good» and «evil» categories by framing them into individual responsibility, less often an experience connected with a religious community. Attitudes of young people, men and women, are increasingly varied, so it is diffi cult to indicate unambiguous trends referring to traditional concepts of secularization and, to a lesser extent, desecularization. In the analyzed cases an increase in student moral liberalism could be observed, especially in the 1990s (in the fi rst phase of transformation). A slight reduction of this trend was observed in the middle of the fi rst decade of the 21st century, which can be related to the infl uence of the teaching of John Paul II present in the Polish public space, symbolically intensifi ed after his death,. Interestingly, marital infi delity is the only behavior which violating religious normative legitimacy is widely disapproved by students. However, is this evaluation still motivated by religion or rather by reference to some form of sacredness such as an intimate bond with another person, closeness 
and mutual devotion, independent of the duration of the sacramental relationship? Ethics assumes as Emmanuel Levinas suggests, «disrupting self-satisfaction with being» [33, p. 10-11], which in practice means a kind of unwanted loneliness combined with the fact that in the fi nal analysis we have only ourselves to rely on. The question whether this uncertainty preceding making a choice is «the only land on which morality can germinate and fl ourish» [34, p. 53]. It remains important for every generation, especially for young people making an effort to exist in a world of fragile social bonds and a defi cit of trust.

\section{REFERENCES}

1. Mariański J. Sociology of morality [in Polish] / J.Mariański. - Lublin: Zakład Wydawniczy KUL,2006a.

2. Mariański J. Society and morality. Studies in Catholic social science and sociology of morality [in Polish]/J.Mariański - Tarnów: Wydawnictwo Biblos,2008b.

3. Eliade M. Sacrum and profanum. On the essence of religiosity [in Polish] / M. Eliade. Warszawa: Wydawnictwo KR, 1999.

4. Giddens A. Transformations of intimacy. Sexuality, love and eroticism in contemporary societies [in Polish]/ A.Giddens - Warszawa: Wydawnictwo Naukowe PWN, 2007.

5. Bauman Z. Post-modern ethics [in Polish] / Z. Bauman. - Warszawa: Wydawnictwo Naukowe PWN, 1996.

6. Pollack D., Müller O., Pickel G. (eds.), The social signifi cance of religion in the enlarged Europe: Secularization, individualization and pluralization / D. Pollack, O. Müller, G. Pickel. - Farnham/Burlington: Ashgate, 2012.

7. Beck U., Giddens A., Lash S., Refl ective modernization. Politics, tradition and aesthetics in the social order of modernity / U. Beck, A. Giddens, S. Lash. - Warszawa: Wydawnictwo Naukowe PWN, 2009.

8. Wójtowicz A.,Contemporary sociology of religion. Ideas, assumptions, programmes [in Polish]/ A.Wójtowicz. - Tyczyn: Wydawnictwo WSS-G, 2004.

9. Mariański J. Moral crisis or transformation of values. Sociological study [in Polish]/ J.Mariański. - Lublin: TN KUL: 2001.

10. Mariański J. Religiosity of Polish society in a European perspective. An attempt at sociological synthesis [in Polish] / J.Mariański. - Kraków: Zakład Wydawniczy «NOMOS», 2004.

11. Mariański $J$. The Religiosity of Polish society from the perspective of secularized Europe, In: I. Borowik (ed.), Religions, Churches and Religiosity in Post-Communist Europe / J. Mariański - Kraków: Zakład Wydawniczy «NOMOS», 2006b. P-81-91.

12. Trzebiatowska M. and Bruce S. Why are woman more religious than men? / M.Trzebiatowska, S. Bruce. - Oxford: Oxford University Press, 2012.

13. Mariański J. Emigration from the Church. Religiosity of Polish youth in the conditions of social change [in Polish] / J. Mariański. - Lublin: Wydawnictwo KUL, 2008a.

14. Mariański J. Marriage and family in the consciousness of senior secondary school leavers stability and change [in Polish] / J.Mariański. - Toruń: Wydawnictwo Adam Marszałek, 2012.

15. Zarzecki M. Religion.pl - the religiosity of students in Web.2.0. paradigma [in Polish], In: S. H. Zaręba, M. Zarzecki (eds.), Between construction and deconstruction of the universe signifi cances. The researches of students religiosity in 1988-1998-2005-2017 years / M. Zarzecki - Warszawa: Kontrast, 2018 [in printing]. 
16. Trubiłowicz E. Students and their world - from martial law to the European Union [in Polish]/ E.Trubiłowicz. - Lublin, Wydawnictwo KUL: 2006.

17. Giza A., Sikorska M.(eds.) Contemporary Polish society [in Polish]/A.Giza, M.Sikorska Warszawa: Wydawnictwo Naukowe PWN, 2012.

18. Catechism of the Catholic Church (CCC) [in Polish], Poznań-Warsaw: Pallottinum, 1994.

19. Abortion in Poland - current legal status. When is abortion in Poland legal? http://www. mjakmama24.pl/rodzice/macierzynstwo/aborcja-w-polsce-aktualny-stan-prawny-kiedyaborcja-jest-legalna,566_9208.html, 2016 [in Polish, accessed: 19/12/2016]

20. Zaręba S. H. Heading towards what kind of religiosity? Studies on Catholicism of Polish youth [in Polish]/ S.H.Zaręba - Warszawa: Zakład Wydawnictw Statystycznych, 2008.

21. Youth 2016. Report from the study fi nanced by the National Bureau for Counteracting Drug Addiction, Warszawa: CBOS, 2016.

22. Więckiewicz B. Marriage as a value and life purpose in the opinion of academic youth [in Polish] / B. Więckiewicz // Społeczeństwo i Rodzina. - 2016. - No. 48 (3). P. 112-128.

23. Baniak $J$. Faithful love and marital infi delity in the evaluation of senior secondary and university students [in Polish]/ Józef Baniak// University Sociological Journal. - 2017. No. 18 (1). P. 15-32.

24. Szawiel T. (ed.) Generation JP2. Past and future of the religious phenomenon [in Polish] / T. Szawiel. - Warszawa: Scholar 2008.

25. Mead M. Culture and identity. Study of generational distance [in Polish] / M.Mead Warszawa: Zakład Wydawniczy PWN, 2000.

26. Bauman Z. On the generation of outcasts [in Polish], transl. Emilia Oksentowicz, Konrad Majo r/ Z.Bauman (the text appeared originally in the «Social Europe Journal»), 2011.

27. Bauman Z., Morality in an unstable world [in Polish] / Z.Bauman. - Poznań: Księgarnia św. Wojciecha, 2006.

28. Bauman Z. Liquid life [in Polish] / Z. Bauman. - Kraków: Wydawnictwo Literackie, 2007a.

29. Sroczyńska M., "Living a life to shred» as a challenge for the modern family (refl ections of a sociologist) [in Polish] / Maria Sroczyńska // University Journal of Sociology - 2017. No18 (1). P. 7-13.

30. Burszta $W . J$. Anchors of certainty. Cultural wars with pop-nationalism in the background [in Polish]/W.Burszta - Warszawa: Wydawnictwo Iskry, 2013.

31. Taylor C. A Secular Age / C.Tylor. - Harvard: M.A.Harvard University Press, 2007.

32. Bauman Z. Together, Apart [in Polish] / Z.Bauman. - Kraków: Wydawnictwo Literackie, 2003.

33. Levinas E. Ethics and Infi nity: Conversations with Philippe Nemo/ E.Levinas - Pittsburgh: Duquesne University Press, 1985.

34. Bauman Z. Chances of ethics in a globalized Word [in Polish]/ Z.Bauman - Kraków: Wydawnictwo Znak, 2007b.

\section{НОРМАТИВНИЙ ВИМІР ІНТИМНОСТІ ШЛЮБНО-СІМЕЙНИХ ВІДНОСИН В ОЦІНКАХ ПОЛЬСЬКИХ СТУДЕНТІВ}

\footnotetext{
У статті розглядається проблема ставлення польських студентів до нормативного виміру інтимності шлюбно-сімейних відносин. Дослідження охоплює п'ять блоків: статеві відносини до шлюбу, використання контрацепції, подружня зрада, розірвання шлюбу та переривання вагітності. Опитування проводилося в 2017 році серед польських студентів. Його результати порівнювалися з результатами аналогічних досліджень, проведених серед академічної молоді розпочинаючи 3 кінця 1980-х років. Показано,
} 
що мораль шлюбно-сімейних відносин, побудована на основі цінностей та принципів відповідно до авторитету римсько-католицької церкви, зазнає суттєвих змін. 3 одного боку, ми маємо справу з індивідуалізацією та суб’єктивізацією змісту інтимного життя, а $з$ іншого з оновленням моральних категорій, котрі значною мірою пов' язуються 3 особистісною відповідальністю і менше - з релігією. Відтак важливим дослідницьким завданням залишається порівняльний аналіз моральних оцінок студентів як представників інших суспільств та релігійних культур, в т.ч. сформованих на основі православного віросповідання.

Ключові слова: інтимність подружньо-родинна, польські студенти, моральна оцінка, релігійні норми. 